\title{
A ressignificação da corporeidade da mulher negra em Becos da memória, de Conceição Evaristo
}

\author{
Angela Rodriguez Mooney*
}

\begin{abstract}
Em meio a tanta desigualdade, ao racismo e ao sexismo que insistem em nos violentar, a chegada da mulher negra à institucionalidade surpreende. Nossa presença assusta o conluio masculino, branco e heteronormativo.

Marielle Franco
\end{abstract}

Ao comentar os versos "My body is an argument I did not start/ In a way I am not aware who made me" da última estrofe do poema And Cold Sunset, a poeta estadounidense Morgan Parker narra a experiência de nascer em um corpo estereotipado, disputado por vários discursos, e a dificuldade de construir uma identidade que perpasse todas essas inscrições: "quando nascemos, passamos metade de nossas vidas desfazendo ideias que foram projetadas sobre nossos corpos, e então construímos uma identidade por em cima disso" (PARKER, 2019, tradução nossa). A construção de uma identidade marcada por um corpo racializado apresenta-se como um desafio a ser atravessado; uma tarefa árdua que implica necessariamente o enfrentamento de uma série de discursos que limitam trajetórias e espaços a serem ocupados. Trata-se de um corpo que carrega o peso das inscrições sociais e culturais bastante específicas, "uma jaula desagradável, na qual terei que me mostrar e passear. É através de suas grades que eu vou falar, olhar, ser visto", como apontou Michel Foucault (1966/2013), mas com o agravante de uma doxa branca, eurocêntrica e patriarcal que, após séculos de exploração da mão-de-obra de pessoas escravizadas de origem africana, construiu e manteve discursos estereotipados, restando aos sujeitos receptores desses discursos difamantes o trabalho de ressignificação.

Ao refletir sobre o lugar que a sociedade brasileira confere à mulher negra, a ativista e ex-ministra Luiza Helena de Bairros disse: "Nós carregamos a marca" (Ribeiro, 2015). Mas de que marca se fala? Jaqueline Lima Santos (2011), militante do Movimento Negro Unificado, explica que uma das marcas seria a deixada pelo colonialismo e o processo de miscigenação, que no Brasil foi celebrada como exemplo do sucesso da "democracia social", na famigerada harmonia entre a Casa Grande e a Senzala. Santos (2011) relembra que a mistura de raças no Brasil foi iniciada por estupros, e o racismo foi escamotado por um discurso focado na sexua-

Doutora em Literatura pela Tulane University, em Nova Orleans, Estados Unidos. E-mail: gemooney@gmail.com. 
lidade e na objetificação do corpo mulher negra. Ao refletir sobre como discursos objetificantes foram construídos e projetados sob a corporeidade feminina, a intelectual e feminista Djamila Ribeiro (2018) relembra a triste história de Saartjie Baartman, a mulher de etnia Khoi-San que, no início do século XIX, foi levada à Londres, e depois à França, e exibida como uma aberração em feiras e eventos devido ao tamanho de suas nádegas. Na Europa, Baartman recebeu o nome de Hottentot Venus, sofrendo os mais diversos abusos e violências. Seu corpo também foi objeto de curiosidade da ciência e explorado para demonstrar sua proximidade aos grandes primatas, marcando o corpo feminino negro com o estigma da anormalidade em comparação ao corpo europeu, esse considerado dentro de um padrão de normalidade. Desse modo, Hottentot Venus personificou a alteridade pela qual se fala e se projeta discursos, e seu corpo foi apropriado pela teoria racista:

Alguém poderia ir além e argumentar que, para a mente européia, a pronunciada esteatopgia de Vênus Hotentote não apenas a fazia parecer sexualmente diferente das mulheres brancas, mas também a colocava muito mais próxima do mundo animal, literal e simbolicamente. Suas nádegas eram um sinal externo de sua natureza primitiva, bem como um emblema de sua luxúria desenfreada (LindFors, 1996, p. 4, tradução nossa).

É também nesse momento que o discurso científico-médico articula categorias de raça e gênero que acabaram por criar uma iconografia de hiperssexualidade da mulher negra: "A sexualidade feminina está ligada à imagem das nádegas, e as nádegas são por excelência as da Hotentote" (GIlman, 1985). A exotização e exploração do corpo da mulher negra, construída durante o colonialismo, permanece nos discursos culturais da atualidade. Ribeiro é categórica ao afirmar que "a história de Baartman se passou há séculos, mas esse estigma ainda recai sobre nós, negras" (2018, p. 142).

Apesar do progresso na construção e ocupação de novos espaços na sociedade, a representação das mulheres e homens negros continua prevalecendo em lugares de violência, pobreza, subalternidade e hiperssexualidade. Apesar de somarem $54,9 \%$ da população brasileira, ${ }^{1}$ pessoas pardas e pretas possuem uma representatividade ínfima entre os meios de produção de discurso de massa. A presença de mulheres e homens negros mostra-se também rarefeita na literatura contemporânea brasileira, como revelou a pesquisa "Personagem do romance brasileiro contemporâneo”, coordenada pela crítica literária Regina Dalcastagnè (2005). A análise dos 258 romances publicados entre 1990 e 2004 pelas três maiores editoras brasileiras, Companhia das Letras, Record e Rocco, apontou que 79,8\% dos personagens são brancos, enquanto apenas 7,9\% são de cor negra e 6,1\% de cor mestiça. ${ }^{2}$ Quando

1 Conforme dados revelados pela Pesquisa Nacional por Amostra de Domicílios Contínua (PNAD Contínua). Ver: Agência IBGE notícias, 2017.

2 Ainda segundo o mesmo estudo, 1,2\% das personagens são indígenas (um total de 15 personagens), o,6\% são orientais (oito personagens), 3,5\% não há indícios e o,8\% a cor não é pertinente (personagens não-humanas). 
avaliados segundo protagonismo nas obras, a presença de personagens negros se torna ainda mais escassa, com apenas 5,8\% ocupando a posição de protagonistas e $2,7 \%$ de narradores. As ausências revelam também silenciamentos temáticos. O racismo, por exemplo, raramente aparece nos romances e, quando está presente, o que se encontra são representações paródicas do discurso racista com uma pretensão de crítica; raramente registra-se o quanto essa prática afeta o dia-a-dia de sujeitos negros e como ela obstrui trajetórias de vidas. Nesse sentido, registra-se o preconceito e o racismo como um assunto do passado, em conformidade com as práticas de manutenção do mito da "democracia racial" (DALCASTAGNÈ, 2005, p. 46).

\section{Representação da mulher negra na literatura: entre o estereótipo e o apagamento}

Quando observada a participação da mulher negra no romance contemporâneo brasileiro, os números caem a ponto de serem contabilizados apenas 3 protagonistas em um universo de 206 protagonistas, e uma única narradora entre 107 narradores. Também relevante é o lugar onde essas mulheres são colocadas. Quando avaliadas segundo a profissão, elas aparecem como empregadas domésticas e prostitutas. A leitura desses dados sugere que a literatura está ancorada a processos estruturais, históricos, políticos e sociais, perpassada por ideologias e preconceitos, como bem aponta o crítico literário britânico Terry Eagleton:

[...] o que descobrimos até agora não é apenas que a literatura não existe da mesma maneira que os insetos, e que os juízos de valor que as constituem são historicamente variáveis, mas que esses juízos têm, eles próprios, uma estreita relação com as ideologias sociais. Eles se referem, em última análise, não apenas ao gosto particular mas aos pressupostos pelos quais certos grupos sociais exercem e mantêm o poder sobre outros (EAgleton, 2003, p. 22).

O esforço de manter uma hegemonia política, econômica e social atua sobre os corpos das mulheres negras, sobre os quais são projetados símbolos da miscigenação de um projeto nacional modernizante, materializado a partir de discursos que os confinam a um lugar que não represente ameaça. O corpo passa então a ser construído segundo os signos de subordinação, exotismo, objetificação e hiperssexualização. Dentro da literatura brasileira, a personificação desses elementos aparece através de personagens como Rita Baiana, do romance $O$ cortiço (189o), de Aluísio Azevedo, que reúne, ao mesmo tempo, atributos de hipersensualidade e vício, e que terminam por corromper o imigrante português Jerônimo, com quem ela se relaciona. Ainda em $O$ cortiço vemos uma segunda representação possível à mulher negra na literatura clássica brasileira: a personagem Bertoleza, a escrava que acredita haver sido libertada pelo português João Romão e, movida apenas pelo amor e gratidão, serve-o com fidelidade e dedicação obstinada. Tal subserviência remete à figura da mãe-preta, à escrava que, apesar de lhe terem sido retirados seus filhos naturais, ama o filho dos sinhôs como se fosse seu. Essa inscrição 
feminina do "escravo fiel" na literatura esteve presente no século XIX através da escrita de alguns autores abolicionistas como José A. C. Júnior e Joaquim Manuel de Macedo, retornando com mais intensidade durante os primeiros anos do modernismo das década de 1930 à década de 1960, quando escritores como José Lins do Rego, Carlos Drummond de Andrade e José Américo de Almeida evocaram com nostalgia a imagem da mãe-preta e o nordeste dos antigos engenhos. Desse modo, a literatura brasileira construiu uma tradição de sub-representação da mulher negra, fixando-a a um lugar de subserviência, reproduzindo mecanismos de simbolização negativa que remetem ao período da escravização, onde o corpo da mulher negra era usado como objeto de produção - mão-de-obra nas plantações e na casa-grande - e sujeito a abusos sexuais e estupros.

Apesar dos avanços de políticas públicas e espaços conquistados, bem como constantes reivindicações para uma representação mais múltipla e variada da mulher negra na sociedade, a produção de discurso pelas indústrias culturais parece resistir a uma mudança de modelos estereotipados. Concomitante a essas práticas, no entanto, existe no Brasil uma literatura construída à margem das grandes editoras e contrária às representações homogêneas de sujeitos negros. Através de poesia, peças de teatro, contos e romances, escritoras como Geni Guimarães, Miriam Alves, Alzira Rufino, Lia Vieira, Cristiane Sobral, Elizandra Souza, Jenyffer Nascimento, Jarid Arraes, Ana Maria Gonçalves, Conceição Evaristo, entre muitas outras, estão ressignificando o corpo feminino negro, reescrevendo-o como elemento fundamental por meio do qual negociam, articulam e constroem identidades múltiplas e complexas, ancoradas em uma ancestralidade valorizada e celebrada.

A força narrativa e o lirismo do texto dessas autoras problematizam o corpo e a corporeidade da mulher negra dentro de um processo de descobertas e ciente da dupla discriminação que sofrem, por serem mulheres em uma sociedade machista, e serem negras em uma sociedade racista (Munanga e Gomes, 2006, p. 133). Diversas são, no entanto, as estratégias e poéticas utilizadas na luta contra esse duplo apagamento. Cientes do local privilegiado de sua escrita, e da condição de locutoras de uma poética corpórea descolonizada, essas autoras forjam novas interpretações que contrariam lugares pré-determinados às mulheres negras. É pensando esse fazer literário contrário às formas representativas da literatura assentadas em imagens racistas e de objetificação, que investigaremos a reescritura da corporeidade no romance Becos da memória, de Conceição Evaristo. De forma específica, analisaremos a forma como o corpo e seus símbolos são representados no romance e o modo como essas construções desestabilizam juízos morais e estereótipos que ancoram o corpo feminino a um passado escravizado.

\section{O corpo negro, lugar de afeto}

Escrito entre os anos de 1987 e 1988, anterior à publicação de seus contos e mesmo do romance Ponciá Vicêncio (2003), Conceição Evaristo conta que Becos da memória permaneceria "esquecido na gaveta" por quase vinte anos, sendo publi- 
cado apenas em 2006. O catálogo da editora Pallas define o romance como uma obra memorialista que "traduz a complexidade humana e os sentimentos profundos de um coletivo que sofre desamparo e preconceito". De fato, o projeto literário de Conceição Evaristo parece querer abarcar um coletivo notável de vidas silenciadas, oprimidas nas favelas e periferias, nos chamados becos, às vezes sem saída. Nesse sentido, é notável que o romance inicie justamente com a lembrança da ausência de um corpo, um corpo misterioso, que causava pavor e despertava uma curiosidade quase febril na menina de treze anos chamada Maria-Nova, protagonista e narradora do romance. É justamente a partir dessa descoberta, de que "vó Rita dormia embolada com ela", que o "desejo dolorido de escrever" (Evaristo, 2006/2017, p. 20) renasce. Desde as primeiras páginas, sabemos então que a necessidade da escrita nasce na protagonista a partir da dor de uma lembrança, de um trauma talvez. Sugerindo um trabalho de memória, a frase "vó Rita dormia embolada com ela" será repetida quatro vezes no curto fragmento. A aliteração traz ritmo e ambiguidade à narrativa, já que saberemos apenas no final do romance o motivo da frase haver causado espanto em Maria-Nova adulta. Saber que a avó não compartilhava a aversão de todos na favela em relação à mulher doente, mas confortava, com o calor de seu corpo, o corpo da amiga coberto por chagas causadas pela hanseníase que, sem tratamento, encontrava-se em estado avançado, desperta na narradora uma ternura dolorida e a vontade de contar a história daqueles que habitaram a favela onde morou na infância. "Havia as doces figuras tenebrosas e havia o amor de vó Rita” (Evaristo, 2017, p. 20), diz Maria-Nova, sugerindo a existência de dois extremos que se completam pelo afeto solicitado e compartilhado. A relação de amor entre essas duas mulheres, onde o sublime coexiste com o grotesco, retornará na obra diversas vezes, sugerindo uma tensão social, que se expressa através do corpo da mulher negra, um corpo historicamente e culturalmente vigiado e controlado pelas relações de poder.

O corpo da amiga da avó, consumido pelas chagas da lepra em estado avançado, poderia ser lido como uma metáfora da desordem social causada pela ordem de desocupação e destruição da favela onde moram as personagens do romance. $\mathrm{O}$ anúncio da destruição da comunidade traz caos à vida de todos na favela, que não desejam sair de suas casas, e tampouco possuem meios para recomeçar uma nova vida em outro lugar. No entanto, é interessante notar que a ênfase da narradora incide na bondade da avó e não no enojo provocado pela doença. A entrega da avó ao cuidado da amiga é absoluta, ela sacrifica sua profissão de parteira e o contato com as demais pessoas na favela para fazer de seu corpo fonte de calor e afeto a esse corpo doente. A proximidade e o afeto que a narradora possui pela avó permite que o sublime sobressaia ao grotesco, e marca a narrativa com um registro sensível sobre a relação de duas mulheres que moram na favela. Essa proximidade também possibilita um deslocamento de representações estigmatizantes do feminino negro na literatura brasileira, transitando entre a servidão e a fidelidade. Figura feminina do "Fiel Escravo", a mãe-preta é um tropo privilegiado de nostalgia do legado cultural do colonialismo e epíteto da subserviência e amor incondicional da mulher escra- 
vizada para com o sinhô-moço. Conceição Evaristo desconstrói discursos enaltecedores da subserviência da mãe-preta ao criar uma personagem que mantém a bondade extrema no cuidado do corpo do outro, mas livre das formas de opressão que a obrigavam a exercer essa função. Nota-se então um trabalho de articulação de discursos que historicamente confinaram o corpo da mulher negra a certas narrativas construídas por padrões hegemônicos a partir do deslocamento da perspectiva de quem narra. A proximidade e o afeto com que Maria-Nova relembra sua história liberta os corpos negros do lugar de alteridade onde foram colocados.

\section{Da feminização da favela à valorização das mulheres lavadeiras: a recuperação de um corpo}

Iris Young chamou de imperialismo cultural a escolha de uma sociedade de eleger a perspectiva de um grupo específico e, a partir dessa escolha, invisibilizar e estereotipar outros grupos. Essa prática implicaria a universalização das experiências culturais do grupo dominante, aceitas então como norma (YounG, 2009, p. 66). Desde sermões, cartas e poemas escritos pelos viajantes jesuítas do século $\mathrm{XVI}$, até romances publicados pelas editoras de maior distribuição na atualidade, a perspectiva majoritariamente adotada na literatura brasileira tem sido a da elite. Raramente a experiência de grupos subalternizados são trabalhados na literatura de modo que tenhamos acesso ao universo e a voz daqueles que não dispõem de capital econômico e cultural na sociedade. Diante de tal ausência, nota-se em Becos da memória a preocupação central de representar diversos grupos silenciados, e, entre eles, o destaque dado às lavadeiras que ocupam na favela uma importância central no sustento das famílias. As lavadeiras são as mães, as avós, as tias dos moradores da favela, e formam um universo feminino que será homenageado:

Escrevo como uma homenagem póstuma à Vó Rita, que dormia embolada com ela, a ela que nunca consegui ver plenamente, aos bêbados, às putas, aos malandros, às crianças vadias que habitam os becos da minha memória. Homenagem póstuma às lavadeiras que madrugavam os varais com roupas ao sol. Âs pernas cansadas, suadas, negras, aloiradas de poeira do campo aberto onde aconteciam os festivais de bola da favela (EvAristo, 2006/2017, p. 17).

Conceição Evaristo contrapõe discursos criados a partir da experiência da colonização e sua permanência nas relações contemporâneas, criando outros discursos carregados de afeto e empatia. No lugar de "hottentots", encontramos "mulheres que madrugam os varais". As pernas suadas das lavadeiras é a imagem celebrada. Seus corpos cansados são alicerces que se erguem no mesmo espaço onde se celebra festivais de bola; mulheres que celebram sua ancestralidade, e resistem. Logo no início do romance fica claro o deslocamento da perspectiva adotada; não interessa aqui as histórias da casa-grande e das sinhás, mas das mulheres que cuidam dessas casas, lavam suas roupas. 


\section{A menstruação em Becos da memória: uma narrativa da opressão}

O deslocamento de perspectiva permite o desenvolvimento de narrativas que evidenciam violências tão brutais quanto aquelas especulares, de assassinatos e torturas exploradas à exaustão em reportagens e produtos culturais sobre o tráfico e suas guerras por território. ${ }^{3}$ Em Becos da memória, o horror, no entanto, é de natureza íntima, vivenciado no silêncio das crianças iniciadas no trabalho de servir, lavar e cuidar da casa dos ricos. É contundente, quando a narradora, ainda na segunda página do romance, descreve como não gostava de lavar os panos cheios de sangue das patroas no tanque comunitário da favela. Seu desconhecimento sobre a origem do sangue revela a pouca idade da menina-lavadeira: "Pensei, por muito tempo, que as patroas, as mulheres ricas mijassem sangue de vez em quando" (Evaristo, 2006/2017, p. 20).

Na literatura canônica a menstruação é tema raramente trabalhado. Mais recentemente, a inclusão dessa temática em uma obra literária acontece em textos investidos de um projeto desmistificante de narrativas construídas sobre o corpo feminino. Tenta-se desassociar o corpo da mulher à ideia de impureza reforçada por textos religiosos ${ }^{4}$ e por discursos médicos do século XIX ${ }^{5}$ que, apesar da distância temporal, ainda hoje é percebida nas práticas discursivas contemporâneas. Em Becos da Memória, entretanto, a referência à "menstruação" surge na construção de uma narrativa que vai além da visibilização e valorização do corpo feminino. Torna-se elemento emblemático de onde podemos refletir sobre a falta de uma perspectiva, dentro do feminismo hegemônico, que considere as especificidades das opressões impingidas sobre as mulheres negras, que além de gênero, sofrem opressões de natureza racial e econômica. A menina negra que lava com nojo o sangue menstrual da patroa é o detalhe capaz de fornecer a experiência mais íntima e silenciada da exploração em que as mulheres negras estão sujeitas ao assumirem a carga dos trabalhos domésticos nas casas ricas. Também sugere uma reflexão sobre a emancipação da mulher branca na sociedade brasileira, que no Brasil aconteceu não somente através de uma renegociação com seus parceiros de funções culturalmente atribuídas exclusivamente a elas, mas também através do emprego, invariavelmente mal remunerado, de mulheres (às vezes meninas) negras. Essas questões são apenas possíveis a partir da adoção da posição subalternizada da mulher dentro da narrativa. Toda a injustiça de uma sociedade aparece expressa de modo sucinto e imagético na voz de Maria-Nova:

3 O crítico literário Eduardo de Assis Duarte muito acertadamente chamou de "brutalismo poético" (2006, p. 306) o estilo de Conceição Evaristo, que trabalha a violência com uma sutilidade que não a mitiga, mas que causa no leitor sensações outras que o espanto.

4 Em Levítico 15:26 (BíbliA, 2020), por exemplo, associa-se a ideia de menstruação à sujeira e impureza, que se estenderia também a "qualquer que tocar essas coisas será imundo; portanto, lavará as suas vestes, e se banhará com água, e será imundo até a tarde”.

5 Durante o século XIX, descobre-se a função dos ovários e documenta-se o fato de que a menstruação ocorre de forma cíclica, como eventos da natureza. Essas "descobertas" reforçaram a ideia de passividade e discursos sobre o papel social da mulher: reprodução e amamentação dos filhos (MANICA, 2003, p. 135-136). 
A torneira, a água, as lavadeiras, os barracões de zinco, papelões, madeiras e lixo. Roupas das patroas que quaravam ao sol. Molambos nossos lavados com o sabão restante. Eu tinha nojo de lavar o sangue alheio. E nem entendia e nem sabia que sangue era aquele. Pensei, por longo tempo, que as patroas, as mulheres ricas, mijassem sangue de vez em quando (Evaristo, 2006/2017, p. 20).

O deslocamento discursivo propiciado pela visibilização de uma temática feminina a partir da perspectiva da mulher subalternizada desestabiliza o cânone literário brasileiro no que se refere ao lugar restrito às mulheres negras. ${ }^{6}$ Ao escolher a perspectiva daquelas que, desde a escravidão, foram silenciadas, Conceição Evaristo dá voz às empregadas domésticas, uma camada social desprivilegiada economicamente e simbolicamente, apesar de somarem no Brasil cerca de 7 milhões de pessoas (InTERnational LABOUR Organization, 2017).

\section{A interiorização da rejeição da estética negra: Ditinha e o espelho}

Em Becos da memória são muitas as personagens subalternizadas que ganham visibilidade. Ditinha é uma delas, mulher que sozinha cuida dos três filhos e do pai inválido. Apesar de trabalhar como empregada doméstica em uma casa rica, mal consegue alimentar sua família. O trajeto da favela à casa onde trabalha lhe é tortuoso para a mulher, que é constantemente confrontada com o contraste entre a miséria em que vive e a beleza do mundo da patroa, no qual pode apenas entrar para servir e, com sorte, trazer aos filhos os restos daquilo que não é consumido na casa:

Ditinha estava cansada, humilhada. Olhou seu barraco, uma sujeira. As roupas amontoadas pelos cantos. Olhou as paredes, teias de aranha e picumãs. Um cheiro forte vinha da fossa. Era preciso jogar um pouco de cal virgem sobre as bostas. Esperou as crianças um pouco mais. Não chegaram. Tirou o pai da cadeira de rodas e o colocou na cama. O pai fedia a sujeira e a cachaça. Lembrou da patroa tão limpa e tão linda como as joias. Pensou que o dia de amanhã seria duro. A casa estaria de pernas pro ar depois da festa. Seriam tantas louças! Na certa sobrariam doces e bolos. A patroa haveria de dividir com ela, com a cozinheira e com a babá. Traria para casa e seria a vez de os olhos dos filhos brilharem mais que qualquer joia. Ela seria um pouquinho feliz (EvARISTO, 2006/2017, p. 104).

No trajeto do barraco onde vive à casa da patroa, Ditinha também seria confrontada diariamente com os modelos excludentes de beleza e sociabilidade. Seu corpo

\footnotetext{
6 Clarice Lispector inclui empregadas domésticas em narrativas complexas, onde a experiência dessas personagens é trabalhada à distância, vistas como uma alteridade a qual se observa e se reflete, adotando, em geral, uma perspectiva mais existencialista que social. A escritora Carolina Maria de Jesus, ao contrário, rompe esse distanciamento com seu celebrado Quarto de despejo (1960), deslocando a perspectiva: a empregada doméstica e moradora da favela é quem reflete sobre o mundo. Becos da memória segue o caminho percursor de Quarto de despejo, e registra em suas páginas a violência que essa experiência profissional, marcada pela profunda desigualdade social e econômica, pode causar no indivíduo.
} 
se torna extensão da casa pobre, que contrasta com a figura da patroa, sendo ela "alta, loira e rica", como revela a passagem em que vê seu rosto refletido no espelho:

Olhou-se no espelho e sentiu-se tão feia, mas feia do que normalmente se sentia. "E se eu tivesse vestidos e sapatos e soubesse arrumar os meus cabelos? (Ditinha detestava os cabelos dela). Mesmo assim eu não assentaria com essas jóias" (Evaristo, 2017, p. 100).

A imagem percebida por Ditinha no espelho revela a ausência de uma tradição de representação de outras belezas além do modelo eurocêntrico. Em seu artigo "Nos Becos Da Memória, a força da narrativa" a crítica literária Simone Pereira Schmidt (2016, p. 105) aponta como a personagem é confrontada com "estritas regras coloniais, racializadas e patriarcais, as quais confinam o corpo da mulher negra em um lugar de negação de si mesma, ou em última instância, em um não-lugar”. O corpo de Ditinha, que já possui os signos e significantes atribuídos à escravidão, sofre também com a imposição do branqueamento como condição de beleza, valores que ganharam contornos nos séculos XIX e XX, sobretudo durante o chamado Estado Novo (1930-1945), quando passaram a fazer parte de um projeto político e ideológico para a formação e organização do estado moderno. Durante o Estado Novo também se estabeleceu a tríplice "branco, católico, apolítico" (Kolfman, 2015) como o ideal estético e de comportamento do povo brasileiro, onde a pessoa negra é fixada como uma alteridade desqualificada ou invisibilizada (Pinto, 2011, p. 97).

\section{A precária percepção de si}

A ausência de uma tradição de representação estende-se também à política, espaço que ainda hoje permanece inacessível aos afro-brasileiros. Políticas excludentes favorecem a internalização da percepção de que mulheres e homens negros não pertencem aos lugares de decisão, mantendo assim o poder nas mãos de uma elite branca. Essa dificuldade em se visualizar ocupando espaços de poder é representada no romance durante o período de eleições, rara circunstância em que eram visitados por candidatos em busca de votos. Findada o período de campanha, restavam os chamados santinhos, folhetos com a imagem do candidato, que seriam reaproveitados como papel higiênico e para brincadeiras, como a votação do candidato mais bonito:

As mulheres e as crianças da favela ficavam votando de brincadeira nos candidatos que elas achavam de rosto mais bonito. Um dia, apareceu um candidato negro. Espalhou também os seus papeizinhos. Poucos escutavam o que o homem tinha a dizer. Diziam mesmo que ele não ganharia nunca. Parecia ser pobre como nós. No concurso de beleza, obteve poucos votos (Evaristo, 2006/2017, p. 117). 
A rejeição de um candidato negro e pobre como eles próprios sugere o posicionamento precário que ocupam em um relacionamento hierárquico construído a partir da fabricação de uma suposta superioridade do branco em relação ao negro. Sobre essa precária percepção de si escreveu a crítica indiana Gayatri Spivak:

O mais claro exemplo disponível de tal violência epistêmica é o projeto remotamente orquestrado, vasto e heterogêneo de se constituir o sujeito colonial como Outro. Esse projeto é também a obliteração assimétrica do rastro desse Outro em sua precária subjetividade (SPIVAK, 2010, p. 47).

Os moradores da favela postos nessa alteridade apreendem discursos que os inferiorizam, fixando-os na própria interpretação de si mesmos, que, como afirma Thomas Bonnici, perpetuaria "a dominação e exerce a exclusão em qualquer situação ou tempo" (2012, p. 249). Esse sistema de opressão que marca os corpos e a subjetividade de indivíduos não opera, no entanto, de modo absoluto. Por ser uma construção discursiva, o corpo também guarda a potência para se tornar um espaço de transgressão que desmorona a constituição da relação de poder que sobre ele é operado (FoucAult, 1975/1987, p. 20-32). Consciente do potencial transgressor da escrita, Evaristo constrói Becos da memória a partir de discursos que retornam ao corpo negro para confrontar a ideologia política da democracia racial e do branqueamento, utilizando repertórios que dialogam com um imaginário de aceitação e rejeição da estética negra e o lugar que ocupa na sociedade brasileira.

\section{Maternidades}

Nesse exercício de resistência e reescritura do corpo feminino, a maternidade é um tema que será representado em sua multiplicidade. No ensaio "Da representação à auto-representação da mulher negra na literatura brasileira", Conceição Evaristo questiona o efeito simbólico da ausência da maternidade nas representações literárias, sugerindo ser resultado da expectativa de um leitor padrão, masculino e branco, que posiciona as mulheres brancas no papel de mãe e as negras no papel de empregada doméstica ou como objeto sexual. Arriscamos dizer que essa ausência também seria resultado do efeito performativo do fazer literário que naturaliza posições, tornando improvável a imaginação de uma mulher negra dentro de seu ambiente familiar, em sua casa, com seus filhos. Essa vivência é substituída pela figura daquela "que causa comiseração ao poeta, cuida dos filhos dos brancos em detrimento dos seus" (Evaristo, 2005a, p. 53), a figura da "mãe preta":

A representação literária da mulher negra, ainda ancorada nas imagens de seu passado escravo, de corpo-procriação e/ou corpo-objeto de prazer do macho senhor, não desenha para ela a imagem de mulher-mãe, perfil desenhado para as mulheres brancas em geral. Personagens negras como Rita Baiana, Gabriela, e outras não são construídas como mulheres que geram descendência. Observando que o imaginário sobre a mulher na 
cultura ocidental constrói-se na dialética do bem e do mal, do anjo e demônio, cujas figuras símbolos são Eva e Maria, e que o corpo da mulher se salva pela maternidade, a ausência de tal representação para a mulher negra acaba por fixar a mulher negra no lugar de um mal não redimido (EvARISTO, 2005b, p. 2).

Becos da memória restitui a maternidade à mulher negra, valorizando uma experiência silenciada na literatura brasileira. Ainda assim, é relevante o fato de a maternidade no romance não ser trabalhada como um evento redentor e de felicidade plena. Ao contrário, são muitas as maternidades em Becos da memória, muitas as mulheres, e muitas as circunstâncias. Talvez em comum seja somente o fato de a maioria dessas maternidades serem vivenciadas sem o apoio de um parceiro, como é o caso de mãe Joana. Mãe da narradora Maria-Nova e de muitos outros filhos, mãe Joana personifica o amor e o sacrifício. Apesar da pobreza extrema e insistência das patroas para que dê alguns de seus filhos - o que assinala a normalização de uma violência que remete ao período escravocrata - ela rejeita as ofertas e mantém todos próximos a si. Mãe Joana luta para que seus filhos estudem, chegando a economizar na comida para comprar-lhes cadernos. ${ }^{7}$ Diferente é a experiência de Ditinha, mãe de três meninos, que tentou interromper cada uma de suas gestações. Na primeira, quando não havia ainda completado 15 anos, "tomou o diabo, bebeu chá de limão-capeta com vinagre, pulou, dançou, sambou e não abortou" (EvARISTO, 2006/2017, p. 102). Na quarta gravidez, sabendo que chás não adiantavam, procurou Maria Cosme, que introduz uma sonda em Ditinha. O procedimento quase a mata:

Sangrou tanto que foi parar no hospital. Os médicos queriam que ela dissesse o nome da "fazedora de anjinhos". Ela não disse mesmo; pelo contrário, se preciso fosse, se pudesse, até esconder Maria Cosme, ela esconderia. Tiveram que retirar o útero e o ovário de Ditinha. Ela respirou aliviada, não criaria barriga mais nunca (EvARISTO, 2006/2017, p. 103).

O alívio de Ditinha, após tornar-se estéril devido a complicações de um aborto clandestino, ilustra a situação desesperadora que mulheres ainda hoje no Brasil enfrentam quando decidem interromper uma gravidez. A situação é extremamente agravada quando enfrentada por mulheres de baixa renda, para as quais

\footnotetext{
7 As representações sobre a maternidade realizadas em Becos da memória, e o papel desempenhado pela personagem mãe Joana, em específico, dialoga com reflexões de pesquisadoras feministas negras, como a realizada por Hale (1980), em que a crítica sugere que as mães negras são mediadoras sofisticadas na negociação entre a cultura dominante opressiva e os valores negros; e a de Dill (1980) que analisa como trabalhadoras domésticas buscam estratégias para que seus filhos tenham mais oportunidades que aquelas que lhes foram oferecidas. No Brasil, algumas pesquisadoras e pesquisadores publicaram análises sobre a maternidade na obra de Conceição Evaristo. Destacamos Dias (2016) que realiza uma análise do tema nos contos "Olhos D'água" e "Quantos filhos Natalina teve”; Oliveira (2015) que analisa a representação das personagens Ponciá, Maria Vicêncio e Nêngua Kainda e, ainda, Silva (2014) que analisa a representação literária da relação entre mulheres negras e a maternidade no conto "Saura Amarantino".
} 
restam apenas métodos tortuosos e extremamente perigosos, como o utilizado em Ditinha.

Descrever as circunstâncias que levam uma mulher a optar por um procedimento de tortuoso sofrimento na tentativa de interromper uma gravidez implica também a problematização de discursos fixados em torno da maternidade. Normatizado em função do chamado "instinto materno", o amor entre mãe e filho aparece frequentemente essencializado e preso à função biológica que naturaliza os papéis de gênero. Becos da memória contribui para o deslocamento dessas prerrogativas ao construir discursos plurais sobre a maternidade. Se o amor de Dona Joana é instintivo e vigilante, próximo a de um animal que se mantém alerta às ameaças ao seu redor, Dora, ao contrário, não possui esse sentimento de resguardo, decide não criar seu único filho, entregando-o sem se arrepender ao pai da criança. Dora desestabiliza também paradigmas no que se refere à sexualidade feminina. Independente, satisfeita com a própria sexualidade, a personagem controla seu destino e é feliz:

Ela era muito conhecida. Era também uma das rezadeiras, das tiradeiras oficiais de terço. Tinha uma voz alta e melodiosa. O corpo melodioso também. Os homens viviam assediando o barraco e o corpo de Dora. Ela vivia feliz. De tempos em tempos, tinha o seu homem, companheiro certo. Eles viviam ali, depois não sei porque partiam. Não se ouvia briga ou choro. O que se ouvia cá de fora, vindo de dentro do barraco de Dora, era sussurro, gemidos prazeirosos de amor. Quem ali passasse altas horas da noite, e parasse, ouvia tudo (EvARISTO, 2006/2017, p. 91).

Interessante notar que Dora é a única personagem no romance que recebe o epíteto de mulata, denominação carregada de um temário erótico criado a partir de um ideário racista que insiste na propensão sensualista da raça negra. Tal marcação, no entanto, é contrariada no momento em que a personagem se destaca na função de rezadeira, colocando-a também em uma posição relevante dentro da vida espiritual da comunidade. O controle que exerce sobre suas relações contraria uma pretensa condição que privilegia o corpo em relação a mente, e supostamente menos intelectualizada. Nesse sentido, Dora rompe com estereótipos de gênero ao demonstrar uma total liberdade no manejo de sua sexualidade e de seus relacionamentos, sem padecer por suas escolhas, ao mesmo tempo em que mantém uma posição de destaque na vida espiritual da comunidade, sendo talvez uma das personagens mais satisfeitas nesse romance de Conceição Evaristo.

Esse processo de assujeitamento, no entanto, é vivenciado de maneira distinta entre as muitas personagens no romance. Se em Dora o prazer aparece articulado com a independência e a felicidade, em outras personagens a voz diaspórica se configura em relatos que remetem às imagens de famílias apartadas e comercializadas nos grandes engenhos do século XIX. É o caso da tia Maria-Velha que, quando criança, provocava lágrimas em seu avô ao lhe recordar a filha que havia 
sido vendida após resistir ao que parece ter sido uma tentativa de abuso sexual do seu dono. O corpo de Maria-Velha carregaria então a marca de um trauma vivenciado coletivamente e transmitido de geração a geração, ato simbólico de resistência que será articulado por Maria-Nova na construção de sua subjetividade. O corpo torturado e depois vendido da tia-avó de Maria-Nova é convocado e se torna um legado a ser recuperado pela menina que carrega consigo a urgência de fazer com que essas vozes sejam ouvidas.

\section{Conclusão}

No artigo "Beyond the flesh: contemporary representations of the black female body in afro-brazilian literature", Flávia Santos de Araújo identifica dois movimentos na poesia de autoras afro-brasileiras nos quais chama de "revisionary" e "revolutionary". A primeira promoveria uma releitura da história brasileira e as fundações de sua identidade nacional, e a segunda articularia e desenvolveria conscientização, autoafirmação e a liberação dos corpos negros (SANTOS, 2016, p. 148). Trazendo-as para Becos da memória, poderíamos afirmar que as personagens do romance justapõem ambas categorias no momento em que a simples inscrição de suas identidades e experiências contrariam o mito da democracia racial e o discurso patriarcal hegemônico que confinou seus corpos aos estereótipos da "mãe preta", da "mulata irresistível" e da "empregada doméstica". Em Becos da memória, a corporeidade negra é libertada das imagens que a ancoram a um passado escravizado, ao mesmo tempo em que a apropriação desse corpo usurpado acontece necessariamente através do resgate de histórias doloridas que têm na colonização sua origem. Como bem apontou o sociólogo e crítico cultural Stuart Hall "dentro de toda exclusão e opressão sofrida na colonização, restou às populações de descendência africana o seu corpo como forma de expressão e significação na diáspora" (2013, p. 324). No caso brasileiro, isso significa não somente transpor atributos e repertórios projetados na construção dos corpos negros, mas também em se reincorporar novas significações. Ao conferir protagonismo às mulheres negras e suas experiências, Becos da memória desloca modos de representação referendados pela literatura canônica, criando territórios simbólicos onde a subjetividade de mulheres negras é visibilizada e valorizada em uma multiplicidade de representações e discursos.

\section{Referências}

Agência Ibge Notícias. Pretos ou pardos são 63,7\% dos desocupados. 17 nov. 2017. Disponível em: https://agenciadenoticias.ibge.gov.br/agencia-noticias/2012agencia-de-noticias/noticias/18o13-pretos-ou-pardos-sao-63-7-dos-desocupados. Acesso em: 19 out. 2019.

Araújo, Flávia Sanntos de. Beyond the flesh: contemporary representations of the black female body in afro-brazilian literature. Meridians: feminism, race, transnationalism, Durham, v. 14, n. 1, p. 148-176, 2016. 
Azevedo, Aluísio. O cortiço. 8 ed. São Paulo: Martin Claret, 2012.

BíbliA. V.T. Levítico. In: Bíblia. Salt Lake City, Utah: A Igreja de Jesus Cristo dos Santos dos Últimos Dias, 2020. [on-line]. Disponível em: https: //www.churchofjesuschrist.org/study/scriptures/ot/lev/15?lang=por. Acesso em: 19 out. 2019.

Bonnici, Thomas. O pós-colonialismo e a literatura: estratégias de leitura. Maringá: Editora da Universidade Estadual de Maringá-EDUEM, 2012.

Dalcastagnè, Regina. A personagem do romance brasileiro contemporâneo: 1990-2004. Estudos de Literatura Brasileira Contemporânea, Brasília, n. 26, p. 13-71, 2005. Disponível em: https://periodicos.unb.br/index.php/estudos/article/view/ 9077. Acesso em: 19 out. 2019.

Dias, Rafaela Kelsen. Maternidade e segregação em Conceição Evaristo. Fórum Identidades, Itabaiana, SE, v. 20, n. 20, abr. 2016. Disponível em: https://seer.ufs.br/ index.php/forumidentidades/article/view/5915. Acesso em: 19 out. 2019.

Dill, Bonnie Thorton. The means to put my children through: child-rearing goals and strategies among black female domestic servants. In: Rodgers-Rose, La France (ed.). The black woman. Beverly Hills, CA: Sage, 198o. p. 107-123.

Duarte, Eduardo de Assis. O bildungsroman afro-brasileiro de Conceição Evaristo. Estudos Feministas, Florianópolis, v. 14, n. 1, p. 305-308, jan./abr. 2006. https: //www.scielo.br/scielo.php?pid=So104-026X2006000100017\&script=sci_arttext. Acesso em: 19 out. 2019.

EAgleton, Terry. A teoria da literatura: uma introdução. 6 ed. São Paulo: Martins Fontes, 2006.

Evaristo, Conceição. Ponciá Vicêncio. Belo Horizonte: Mazza Edições, 2003.

Evaristo, Conceição. Da representação à auto-apresentação da mulher negra na literatura brasileira. Revista Palmares, Brasília, a. 1, n. 1, p. 52-57, ago. 2005a. Disponível em: http://www.palmares.gov.br/sites/ooo/2/download/52\%20a\%2057.pdf. Acesso em: 19 out. 2019.

Evaristo, Conceição. Gênero e etnia: uma escre(vivência) de dupla face. In: MoREIRA, Nadilza Martins de Barros; SchneIDER, Liane (eds.). Mulheres no mundo: etnia, marginalidade e diáspora. João Pessoa: Ideia Editora, 2005b. p. 201-212.

Evaristo, Conceição. Becos da Memória. Rio de Janeiro: Pallas, 2006/2017.

Foucault, Michel. Vigiar e punir: nascimento da prisão. Petrópolis: Vozes, 1975/1987.

FoucAult, Michel. O corpo utópico: heterotopias. São Paulo: n-1 Edições, 1966/2013. 
Franco, Marielle. O novo sempre vem. Le Monde Diplomatique Brasil, n. 126, 8 jan. 2018. Disponível em: http://diplomatique.org.br/o-novo-sempre-vem/. Acesso em: 19 out. 2019.

Gilman, Sander L. The hottentot and the prostitute: toward an iconography of female sexuality. Ithaca and London: Cornell University Press, 1985.

Hale, Janice. The black woman and child rearing. In: Rodgers-Rose, La France (ed.). The black woman. Beverly Hills, CA: Sage, 1980. p. 79-87.

HALl, Stuart. Da diáspora: identidades e mediações culturais. 2 ed. Belo Horizonte: Editora UFMG, 2013.

International Labour Organization. Domestic workers across the world: global and regional statistics and the extent of legal protection. Disponível em: https:// www.ilo.org/global/topics/domestic-workers/lang--en/index.htm. Acesso em: 10 nov. 2019.

Jesus, Carolina Maria de. Quarto de despejo: diário de uma favelada. São Paulo: Ática, 2012.

KoIfMAN, Fabio. Imigrante ideal: o Ministério da Justiça e a entrada de estrangeiros no Brasil (1941-1945). Rio de Janeiro: Civilização Brasileira, 2015.

Lindfors, Bernth. Hottentot, Bushman, Kaffir: Taxonomic Tendencies in Nineteenth-Century Racial Iconography. Nordic Journal of African Studies, v. 5, n. 2, p. 1-30, 1996. Disponível em: http://www.njas.helsinki.fi/. Acesso em: 19 out. 2019 .

MANica, Daniela Tonelli. T. Supressão da menstruação: ginecologistas e laboratórios farmacêuticos re-apresentando natureza e cultura. 2003. Dissertação. (Mestrado em Antropologia) - Universidade Estadual de Campinas, Campinas, 2003. Disponível em: http://www.repositorio.unicamp.br/bitstream/REPOSIP/281973/1/ Manica_DanielaTonelli_M.pdf. Acesso em: 19 out. 2019.

Munanga, Kabengele; Gomes, Nilma Lino. O negro no Brasil de hoje. São Paulo: Global Editora, 2006.

Oliveira, Ana Ximenes Gomes de. Fêmea-matriz: a maternidade em Ponciá Vicêncio, de Conceição Evaristo. 2015. Dissertação (Mestrado em Letras) - Universidade Federal da Paraíba, João Pessoa, 2015.

PARKer, Morgan. Magical negro carries the weight of history. [Entrevista concedida a] Mary Louise Kelly. American University Radio, Washington, 12 fev. 2019. [on-line]. Disponível em: https://wamu.org/story/19/o2/12/magical-negro-carriesthe-weight-of-history/. Acesso em: 19 out. 2019.

PINTo, Felipe Menezes. O vermelho e o negro: intolerância, construção da identidade nacional e práticas educativas durante o estado novo (1937 1945). 2011. Dissertação (Mestrado em História). Universidade Federal de Minas Gerais, Belo 
Horizonte, 2011. Disponível em: https://repositorio.ufmg.br/handle/1843/BUOS8MJFDE. Acesso em: 19 out. 2019.

Ribeiro, Djamila. Quem tem medo do feminismo negro? São Paulo: Companhia das Letras, 2018.

Ribeiro, Djamila. "O Corpo Da Mulher Negra Como Pedaço de Carne Barata." Blog Do Sakamoto. Disponível em: https://blogdosakamoto.blogosfera.uol.com.br/ 2015/o4/o-corpo-da-mulher-negra-como-pedaco-de-carne-barata/. Acesso em: 6 ago. 2020 .

SAntos, Jaqueline Lima. Mulheres Negras: Nós Carregamos a Marca. [blog]. Disponível em: http://dianacostaeduhistoria.blogspot.com/2011/o1/mulheres-negrasnos-carregamos-marca.html. Acesso em: 19 out. 2019.

Schmidt, Simone Pereira. Nos Becos da Memória, a força da narrativa. In: DuARte, Constância Lima; Cortês, Cristiane; Pereira, Maria do Rosário A. (eds.). Escrevievências: identidade, gênero, violência na obra de Conceição Evaristo. Belo Horizonte: Idea, 2016. p. 101-107.

Silva, Kelly Cardoso da. A representação da mulher em contos de Conceição Evaristo e Paulina Chiziane: perspectivas de gênero e maternidade. 2014. (Monografia). Universidade de Brasília, Brasília, 2014. Disponível em: https://bdm.unb.br/ bitstream/10483/8703/1/2014_KellyCardosodaSilva.pdf. Acesso em: 19 out. 2019.

SpIVAK, Gayatri. Pode o subalterno falar? Belo Horizonte: Editora UFMG, 2010.

Young, Iris. Marion. Five faces of oppression. In: Henderson, George; WatersTONE, Marvin (eds.). Geographic thought: a praxis perspective. London; New York: Routledge, 2009. p. 55-71. Disponível em: https://www.muthar-alomar.com/wpcontent/uploads/2013/o1/Geographic-Thought.pdf. Acesso em: 19 out. 2019.

Recebido em 10 de dezembro de 2019.

Aprovado em $1^{\circ}$ de março de 2020.

\section{Resumo/Abstract/Resumen}

A ressignificação da corporeidade da mulher negra em Becos da memória, de Conceição Evaristo

\section{Angela Rodriguez Mooney}

Este artigo investiga a reescritura da corporeidade da mulher negra no romance Becos da memória de Conceição Evaristo, publicado em 2006. Intenciona-se analisar a forma como o corpo e seus símbolos são representados no romance e como essas construções desestabilizam juízos morais e estereótipos que ancoram o corpo da mulher negra a um passado escravizado, criando novas territorialidades onde a subjetividade da mulher negra é visibilizada e valorizada. 
Palavras-chave: identidade, Conceição Evaristo, Becos da memória, branqueamento, diáspora, corporeidade negra.

Giving new meaning to the corporeality of black women in Becos da memória, by Conceição Evaristo

\section{Angela Rodriguez Mooney}

This article investigates the rewriting of the corporeality of black women in Conceição Evaristo's novel Becos de la Memoria (2006). It analyses how the body and its symbols are represented in the novel and how these constructions destabilize moral judgements and stereotypes that anchor the body of the black woman to an enslaved past by creating new territorialities where the subjectivity of the black woman is made visible and valued.

Keywords: Identity, Conceição Evaristo, Becos da memória, African diaspora, corporeality.

La resignificación de la corporeidad de la mujer negra en Becos da Memória, de Conceição Evaristo

\section{Angela Rodriguez Mooney}

En este artículo se investiga la reescritura de la corporeidad de la mujer negra en la novela Becos da memória (2006), de Conceição Evaristo. Se trata de analizar la forma en la que el cuerpo y sus símbolos aparecen representados en la novela y cómo esas construcciones desestabilizan juicios morales y estereotipos que anclan el cuerpo de la mujer negra a un pasado esclavizado, creando nuevas territorialidades donde la subjetividad de la mujer negra es visibilizada y valorada.

Palabras clave: identidad, Conceição Evaristo, Becos da memória, diáspora africana, corporeidad negra. 